\title{
Seismic Imaging
}

A practical approach 



\section{Seismic Imaging}

A practical approach

\section{Jean-Luc Mari \\ Manuela Mendes}

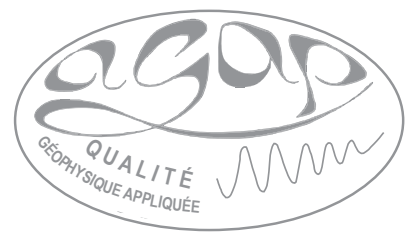

edpsciences 
DOI: $10.1051 / 978-2-7598-2351-2$

ISBN(ebook) : 978-2-7598-2351-2

This book is published in under Open Access Creative Commons License CC-BY-NC-ND (https://creativecommons.org/licenses/by-nc-nd/4.0/en/) allowing non-commercial use, distribution, reproduction of the text, via any medium, provided the source is cited.

(C) EDP Sciences, 2019 